JURNAL ILMIAH PETERNAKAN TERPADU Vol. 8(3): 111 - 119, November 2020

Tria Deviana Putri et al.

Terakreditasi Peringkat 3 Kemenristekdikti RI No. 21/E/KPT/2018

ISSN: 2614-0497

\title{
FAKTOR-FAKTOR YANG MEMENGARUHI KEBERHASILAN INSEMINASI BUATAN PADA SAPI DI KABUPATEN ASAHAN, SUMATERA UTARA
}

\section{Factors Affecting the Success of Artificial Insemination on Cattle in Asahan District, North Sumatera}

\section{Tria Deviana Putri, Tongku Nizwan Siregar, Cut Nila Thasmi, Juli Melia, Mulyadi Adam*}

Faculty of Veterinary Medicine, Universitas Syiah Kuala

Teuku Hasan Kreung Kalee No.4, Kopelma Darussalam, Syiah Kuala, Banda Aceh, Aceh 23111

*E-mail : mulyadi_adam@unsyiah.ac.id

Submitted : April 15, $2020 \quad$ Accepted : November 29, 2020

\begin{abstract}
ABSTRAK
Inseminasi buatan dikenal oleh peternak sebagai teknologi reproduksi ternak yang efektif. Penelitian ini bertujuan mengetahui faktor-faktor yang memengaruhi keberhasilan inseminasi buatan pada sapi di Kabupaten Asahan yang dipelihara secara intensif. Metode penelitian ini adalah metode survey, menggunakan data primer dan data sekunder. Data primer diperoleh dengan cara membagikan kuesioner dan wawancara langsung ke peternak sebagai tambahan informasi, sedangkan data sekunder didapat dari inseminator terkait tentang hasil inseminasi buatan di Kabupaten Asahan. Kuesioner yang digunakan mencakup pertanyaan tentang karakteristik sapi seperti: status kebuntingan sapi (konfirmasi dari petugas inseminator), jenis sapi, umur sapi, skor kondisi tubuh sapi, jumlah inseminasi buatan sampai bunting, tanda-tanda berahi, waktu pelaksanaan inseminasi buatan, bulan pelaksanaan inseminasi buatan, lama birahi pascapartus, jenis straw, jumlah dosis inseminasi, jarak waktu pelaporan berahi sampai dengan IB dilaksanakan, pakan sapi, ternak dikandangkan serta profil peternak dengan 75 responden peternak dari lima kecamatan. Data dianalisis menggunakan stepwise regression. Hasil penelitian menunjukkan bahwa dari 114 ekor ternak sapi betina yang dilakukan IB, sebanyak 76,3\% mengalami kebuntingan dan $23,7 \%$ tidak mengalami kebuntingan. Variabel independen yang mempunyai korelasi paling kuat adalah umur sapi (sig. 0,006), jarak waktu pelaporan sampai IB (sig. 0,001), serta pakan ternak sapi (sig. 0,004). Kesimpulan penelitian bahwa faktor-faktor yang memengaruhi keberhasilan inseminasi buatan pada sapi di Kabupaten Asahan adalah umur sapi, jarak waktu pelaporan sampai inseminasi buatan dilaksanakan, dan pakan.
\end{abstract}

Kata kunci: Faktor keberhasilan, Inseminasi buatan, Jenis pakan, Umur sapi

\section{ABSTRACT}

Artificial insemination is known by breeders as an effective reproductive technology for livestock. This study aimed to determine the factors that influence the success of artificial insemination in cattle in the Asahan District. The method of this research was the survey method, using primary data and secondary data. Primary data was obtained by distributing questionnaires and interviews directly to farmers as additional information, while secondary data obtained from inseminators related to the results of artificial insemination in the Asahan District. The questionnaire used included questions about cattle characteristics such as pregnancy status, type of cattle, age of cattle, body condition score at artificial insemination, number of artificial insemination to pregnant, oestrus signs, time implementation of artificial insemination, the month of implementation of artificial insemination, duration of postpartum heat, type of straw, number of insemination doses, the distance of reporting of lust up to artificial insemination, cattle feed, stocked cattle and farmer identity with 75 farmer respondents from 5 sub-district. Data were analyzed using stepwise regression with the help of SPSS. The results showed that of the 114 female cattle carried out by artificial insemination, $76.3 \%$ had a pregnancy and $23.7 \%$ had no pregnancy. The independent variable which had the strongest correlation was the age of the cattle (sig. 0.006), the reporting distance to artificial insemination (sig. 0.001), and cattle feed (sig. 0.004). The three factors that have the strongest correlation were based on sig. $<0.05$ so that it had a significant effect on the success of artificial insemination in the Asahan Regency.

Keywords: Age of cattle, Artificial insemination, Success factor, Type of feed. 


\section{PENDAHULUAN}

Kebutuhan daging sapi setiap tahunnya meningkat seiring dengan bertambahnya jumlah penduduk, peningkatan pendapatan dan kesejahteraan masyarakat, serta semakin tingginya pengetahuan tentang pentingnya protein hewani. Selain itu, penyediaan daging masih tergolong rendah apabila dibandingkan dengan permintaannya. Kesenjangan ini dapat dikurangi dengan berbagai upaya yang mampu meningkatkan produktivitas, terlebih pada peternak sapi potong rakyat (Nuryadi dan Wahjuningsih, 2011). Salah satu upaya yang dilakukan oleh pemerintah daerah adalah berusaha meningkatkan populasi dan produktivitas serta mutu genetik ternak melalui penerapan teknologi reproduksi ternak baik teknologi inseminasi buatan (IB) maupun transfer embrio (Sibagariang et al., 2010)

Inseminasi buatan adalah usaha manusia memasukkan spermatozoa ke dalam saluran reproduksi betina dengan menggunakan peralatan khusus (Hastuti, 2008). Inseminasi buatan dikenal oleh peternak sebagai teknologi reproduksi ternak yang efektif. Secara umum teknik IB terdiri atas dua metode yakni metode inseminasi vaginaskop atau spekulum dan metode rectovaginal (Selk, 2007; Susilawati, 2011). Inseminasi buatan berfungsi untuk perbaikan mutu genetik, pencegahan penyakit menular, recording yang lebih akurat, biaya lebih murah, mencegah kecelakaan dan transmisi penyakit yang disebabkan oleh pejantan (Kusumawati dan Leondro, 2014). Inseminasi buatan dikatakan berhasil bila sapi induk yang diinseminasi menjadi bunting.

Pelaksanaan IB di Provinsi Sumatera Utara pertama kali terlaksana pada tahun 2007 yang mengikutsertakan sembilan kabupaten dan dua kota yakni, Kabupaten Mandailing Natal, Deli Serdang, Langkat, Simalungun, Karo, Asahan, Labuhan Batu, Tapanuli Selatan, Serdang Bedagai dan Kota Binjai serta Medan. Populasi sapi di Sumatera Utara sangat tinggi dan hampir di setiap kabupaten/kota terdapat ternak sapi. Provinsi Sumatera Utara menargetkan swasembada daging sapi pada tahun 2010. Target di atas didasarkan dari populasi ternak sapi potong dan sapi perah per kabupaten/kota dan juga sistem pemeliharaan ternak di Provinsi Sumatera Utara (Sibagariang et al., 2010). Salah satu kabupaten di Sumatera Utara yang memiliki angka keberhasilan IB yang relatif baik adalah Kabupaten Asahan yakni hampir mencapai 70\%. Informasi dari data Dirjen Peternakan dan Kesehatan Hewan Kementerian Pertanian tahun
2017 menyebutkan bahwa di Kabupaten Asahan dari 19.390 ekor akseptor, jumlah akseptor yang berhasil bunting mencapai 12.991 ekor.

Faktor keberhasilan IB dipengaruhi oleh pengetahuan peternak dalam gejala berahi, pelaksanaan IB, pengalaman inseminator, dan kualitas spermatozoa (Toelihere, 1997). Menurut Hoesni (2015), faktor-faktor yang memengaruhi IB adalah fertilitas, keterampilan inseminator, deteksi berahi, waktu inseminasi, jumlah spermatozoa, dosis inseminasi dan komposisi semen serta beberapa hal yang dapat mempengaruhi IB adalah kondisi ternak, tingkat pendidikan peternak, pengalaman melahirkan untuk sapi, kualitas sperma yang baik dan tenaga inseminator yang berpengalaman. Salah satu kunci keberhasilan IB adalah sapi dipelihara secara intensif dengan cara dikandangkan. Hal ini akan memudahkan dalam deteksi berahi serta memudahkan petugas untuk melaksanakan IB (Ihsan, 2010). Berdasarkan latar belakang tersebut maka dibutuhkan suatu analisis untuk mengetahui faktor-faktor yang memengaruhi keberhasilan inseminasi buatan pada sapi di Kabupaten Asahan sehingga dapat dijadikan acuan dalam meningkatkan keberhasilan IB di daerah lain yang hasil-hasil inseminasinya belum baik.

\section{MATERI DAN METODE}

\section{Materi}

Penelitian ini dilakukan di Kabupaten Asahan pada bulan Januari-Maret 2019. Data yang digunakan adalah data inseminator terkait hasil IB di Kabupaten Asahan. Objek penelitian ini adalah ternak sapi yang diinseminasi dan peternak yang sapinya diinseminasi oleh inseminator dan dipelihara secara intensif.

\section{Metode}

Metode penelitian ini adalah metode survey, menggunakan data primer dan data sekunder. Data primer didapat dengan cara membagikan kuisioner dan wawancara langsung ke peternak sebagai tambahan informasi, sedangkan data sekunder didapat dari inseminator terkait tentang hasil inseminasi buatan di Kabupaten Asahan.

\section{Persiapan Kuisioner}

Kuisioner yang digunakan mencakup pertanyaan tentang karakteristik sapi seperti: status kebuntingan sapi (bunting/tidak bunting yang diperoleh dari hasil pemeriksaan inseminator), jenis sapi, umur sapi, skor kondisi tubuh pada saat di IB, sapi yang digunakan (dara/dewasa), jumlah perkawinan sapi pertahun, 
jumlah IB sampai bunting, tanda-tanda berahi (jelas/tidak), waktu pelaksanaan IB (pagi/sore), bulan pelaksanaan IB, lama berahi pasca partus, jenis straw, jumlah dosis inseminasi, jarak waktu pelaporan berahi sampai dengan IB, pakan sapi serta identitas peternak.

\section{Responden}

Penentuan responden dilakukan dengan cara cuplikan disengaja (purpose sampling) yang mengacu pada informasi dari data inseminator di Kabupaten Asahan. Lokasi penelitian yaitu lima kecamatan yaitu: Kecamatan Air Joman, Kecamatan Silau Laut, Kecamatan Kisaran Timur, Kecamatan Tanjung Balai, dan Kecamatan Sei Dadap dari 25 kecamatan di Kabupaten Asahan yang dipilih berdasarkan kriteria sapinya diinseminasi oleh inseminator yang sama dan memiliki akseptor terbanyak di Kabupaten Asahan, kemudian mengambil sampel lima desa dari tiap kecamatan dan sampel tiga peternak dari tiap desa. Kriteria yang digunakan untuk memilih sampel di level desa dan peternak menggunakan kriteria yang sama saat memilih sampel kecamatan, sehingga total sampel peternak yang digunakan adalah 75 peternak.

\section{Analisis Data}

Data yang diperoleh dari penelitian ini akan dianalisis menggunakan stepwise regression.

\section{HASIL DAN PEMBAHASAN}

Profil peternak sebagai responden pada penelitian ini meliputi umur, jenis kelamin, tingkat pendidikan, pekerjaan utama peternak, pengalaman beternak, jumlah kepemilikan ternak seluruhnya dan jumlah kepemilikan ternak betina seperti yang disajikan pada Tabel 1. Persentase profil responden peternak di Kabupaten Asahan terlihat baik dan mendukung terhadap peningkatan produktivitas di bidang peternakan. Malotes (2016) menyatakan bahwa usia 25 sampi 45 masih tergolong usia yang sangat produktif.

Tabel 1. Profil responden peternak sapi di Kabupaten Asahan (Profile of respondents of cattle breeders in Asahan District)

\begin{tabular}{|c|c|c|}
\hline Karakteristik (Characteristics) & Jumlah (Amount) & $\%$ \\
\hline \multicolumn{3}{|l|}{ Umur (Age) } \\
\hline$>45$ tahun & 54 & 72,0 \\
\hline$<45$ tahun & 21 & 28,0 \\
\hline \multicolumn{3}{|l|}{ Jenis kelamin (Gender) } \\
\hline Laki-laki & 75 & 100,0 \\
\hline Perempuan & 0 & 0,0 \\
\hline \multicolumn{3}{|c|}{ Tingkat pendidikan (Education Level) } \\
\hline Sekolah Dasar & 45 & 60,0 \\
\hline Sekolah Menengah Pertama & 20 & 26,6 \\
\hline Sekolah Menengah Atas & 10 & 13,3 \\
\hline Perguruan Tinggi & 0 & 0,0 \\
\hline \multicolumn{3}{|l|}{ Pekerjaan utama (Main job) } \\
\hline Peternak & 3 & 4,0 \\
\hline Petani & 40 & 53,3 \\
\hline Pegawai Negeri Sipil & 1 & 1,3 \\
\hline Wiraswasta & 31 & 41,3 \\
\hline \multicolumn{3}{|c|}{ Pengalaman beternak (Breeding experience) } \\
\hline$<5$ tahun & 32 & 42,6 \\
\hline$>5$ tahun & 43 & 57,3 \\
\hline \multicolumn{3}{|l|}{ Jumlah sapi (Number of cattle) } \\
\hline$<4$ ekor & 35 & 45,4 \\
\hline$>4$ ekor & 42 & 54,6 \\
\hline \multicolumn{3}{|c|}{ Jumlah kepemilikan ternak betina (Number of heifer) } \\
\hline$<4$ ekor & 70 & 93,3 \\
\hline 4-7 ekor & 4 & 5,3 \\
\hline 8-10 ekor & 0 & 0,0 \\
\hline$>10$ ekor & 1 & 1,3 \\
\hline
\end{tabular}


Pada Tabel 1 terlihat bahwa umur responden lebih tinggi persentase pada usia $>45$ tahun sebanyak $72 \%$ dibandingkan usia $<45$ tahun sebanyak 28\%. Prayitno (2018) bahwa umur dapat memengaruhi keseriusan dalam menjalankan usaha. Semakin dewasa seseorang dan dengan beban hidup yang ditanggung akan semakin terpacu untuk mencari alternatif usaha atau sungguh-sungguh dalam menjalankan usaha. Menurut Soekartawi (1988) umur peternak selaku tenaga kerja pada usaha tani di pedesaan sering menjadi penentu besar kecilnya penerimaan. Salah satu faktor yang memengaruhi pendapatan dan efisiensi ekonomi yaitu umur peternak (Annisa et al., 2018). Prayitno (2018) menyatakan bahwa usia mempunyai pengaruh terhadap produktivitas kerja pada jenis pekerjaan yang mengandalkan tenaga fisik.

Tingkat pendidikan responden sebagian besar pada tingkat SD dan hanya sedikit yang mencapai tingkat lanjutan dengan persentase masing-masing yakni tingkat pendidikan SD (45\%), SMP (26,6\%), SMA (1,3\%), dan Perguruan Tinggi $(0 \%)$. Menurut Hifiziah dan Astuti (2015), meskipun dengan tingkat pendidikan yang rendah, sikap dan pandangan peternak tentang usaha tani ternaknya sudah mulai maju. Belajar dari pengalaman dan pengetahuan menyebabkan kemampuan peternak untuk mengambil keputusan semakin baik dan cermat. Bertolak belakang dengan pendapat Adnan (2018) bahwa semakin tinggi tingkat pendidikan maka tingkat pengetahuan peternak terhadap dunia peternakan semakin luas, dibandingkan dengan peternak yang berpendidikan rendah ataupun tidak pernah sekolah. Rendahnya tingkat pengetahuan peternak disebabkan kurangnya penyuluhan oleh pemerintah atau lembagalembaga terkait. Ditambahkan oleh Mosher (1987), melalui pendidikan petani mempunyai pengetahuan, keterampilan dan cara baru dalam melakukan kegiatan usaha sehingga dengan pendidikan yang lebih tinggi hasil usaha jadi lebih baik.

Pekerjaan utama peternak yang memiliki persentase tertinggi adalah petani sebesar $(53,3 \%)$. Hastuti $\left(2008^{a}\right)$ menyatakan bahwa pekerjaan utama responden peternak sebagian adalah petani, menunjukkan bahwa peternakan merupakan usaha sampingan. Sabrani (1989) mengatakan bahwa untuk menghadapi risiko usaha seperti kegagalan produksi, petani melakukan diversifikasi dan melakukan usaha sambilan sebagai salah satu sumber pendapatan untuk memenuhi kebutuhan rumah tangganya.

Berdasarkan Tabel 1 diketahui bahwa peternak yang sudah berpengalaman $<5$ tahun persentasenya sebesar $42,6 \%$ dan $>5$ tahun persentasenya sebesar $57,3 \%$. Hal ini sependapat dengan Ananta et al. (2015) bahwa pengelompokan tingkat pengalaman petani dan peternak disebut berpengalaman dalam usaha ternaknya apabila telah menggeluti bidang pekerjaannya selama lebih dari 10 tahun, cukup berpengalaman bila menggeluti bidang usahanya selama 5-10 tahun dan kurang berpengalaman bila baru menggeluti pekerjaannya kurang dari 5 tahun.

Menurut Delfina (2001), pengalaman memengaruhi kemampuan seorang peternak untuk memelihara sapinya. Semakin banyak atau lama pengalaman peternak, maka semakin besar kemampuannya untuk beternak. Pengalaman beternak responden sangat bervariasi mulai dari satu tahun, bahkan sampai lebih dari lima tahun. Pengalaman peternak umumnya berkorelasi positif terhadap produktivitas, dimana semakin lama pengalaman beternak maka produktivitas yang dihasilkannya semakin bertambah, karena semakin tinggi tingkat pengalaman beternak, maka keterampilan dan sikap terhadap usaha ternak yang dikelolanya akan semakin baik (Kusnadi et al., 1983).

Peternakan sapi di Kabupaten Asahan bersifat peternakan rakyat, kepemilikan ternak sapi responden sebagian besar lebih dari empat ekor dengan rata-rata kepemilikan 6-8 ekor, hal ini dikarenakan peternak menjadikan ternak sebagai usaha sambilan untuk mendapatkan sumber pendapatan yang memenuhi kebutuhan perekonomian peternak. Hastuti (2008 ${ }^{\mathrm{a}}$ ) menyatakan untuk mencapai break event point (BEP) paling tidak peternak harus memiliki 5-10 ekor sapi. Hal ini sejalan dengan pernyataan Astuti et al. (2000) bahwa jumlah pemilikan ternak sangat menentukan tingkat pendapatan, karena semakin besar jumlah pemilikan ternak maka semakin efisien karena meningkatkan jumlah penerimaan dan menekan total biaya produksi.

Ternak sapi di Kabupaten Asahan pada penelitian ini digambarkan melalui beberapa karakteristik seperti umur sapi, jenis sapi, skor kondisi tubuh sapi, waktu pelaksanaan IB, bulan dilakukannya IB, jumlah IB sampai terjadinya kebuntingan, lama berahi pascapartus, jenis straw, dosis inseminasi, jarak waktu pelaporan sampai IB, pakan yang diberikan, tanda-tanda berahi, sapi dikandangkan atau tidak dan status keberhasilan (bunting atau tidak bunting) seperti yang disajikan pada Tabel 2 . 
Tabel 2. Karakteristik faktor-faktor yang memengaruhi keberhasilan inseminasi buatan di Kabupaten Asahan (Characteristics of the factors that influence the success of artificial insemination in Asahan District)

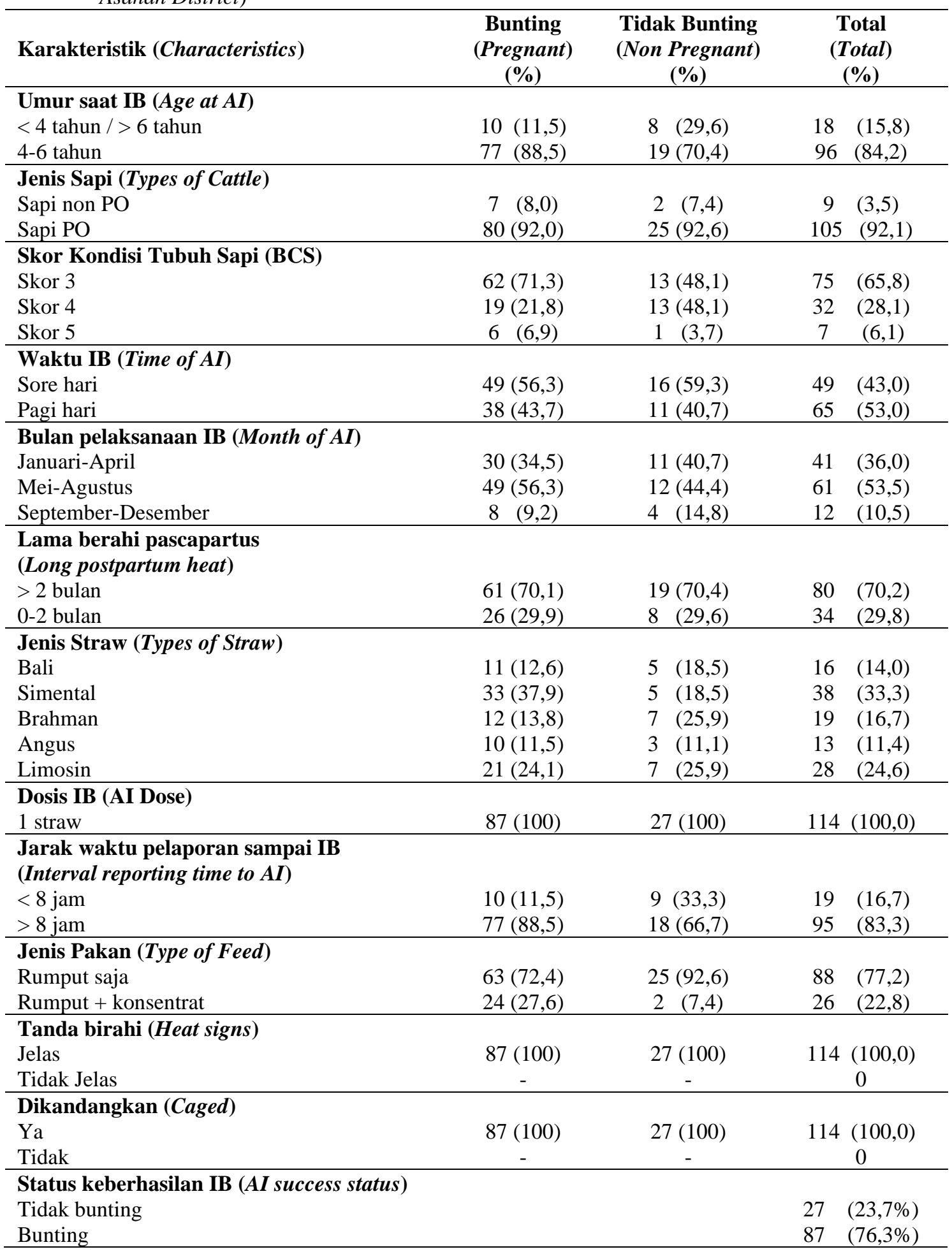

Pemilihan parameter ini berdasarkan Kusumawati dan Leondro (2014) bahwa faktor yang memengaruhi keberhasilan IB yaitu sumber daya manusia (peternak dan ketepatan deteksi berahi), fisiologi sapi (umur sapi, jenis sapi, pakan, kandang, cuaca dan skor kondisi tubuh sapi). Ditegaskan kembali dari hasil penelitian Adnan (2018), keberhasilan IB pada ternak 
ditentukan oleh beberapa faktor, yaitu kualitas semen beku (straw), deteksi birahi dan pelaporan, keterampilan inseminator, teknik IB, kualitas dan kuantitas pakan dan skor kondisi tubuh sapi. Faktor ini berhubungan satu dengan yang lain dan bila salah satu nilainya rendah akan menyebabkan hasil IB juga akan rendah.

Inseminasi buatan pada ternak sapi pada penelitian ini umumnya dilakukan pada sapi yang berumur 4-6 tahun $(84,2 \%)$ dan jenis sapi PO merupakan sapi yang memiliki persentase tertinggi $(92,1 \%)$. Ternak sapi yang dilakukan IB umumnya memiliki skor kondisi tubuh (SKT) 3 $(65,8 \%)$ dan skor SKT $4(28,1 \%)$ dengan interval skoring 1-5. Waktu pelaksanaan IB terlihat tidak menunjukan persentase yang jauh berbeda yaitu pagi hari $(43,0 \%)$ dan sore hari $(53,0 \%)$. Pada penelitian ini persentase tertinggi peternak melakukan IB yaitu pada bulan Mei-Agustus $(53,5 \%)$. Jumlah IB sampai terjadinya kebuntingan pada ternak sapi umumnya hanya satu kali $(75,4 \%)$.

Ternak sapi yang telah dinseminasi mengalami lama berahi pascapartus dengan jangka waktu lebih dari dua bulan $(70,2 \%)$. Jenis straw yang digunakan biasanya sapi simmental $(33,3 \%)$, sapi limosin $(24,6 \%)$, sapi brahman $(16,7 \%)$, sapi bali $(14,0 \%)$, dan sapi angus $(11,4 \%)$ sedangkan dosis inseminasi yang diberikan sebanyak satu straw (100,0\%). Jarak waktu pelaporan peternak sampai dilakukannya IB oleh inseminator umumnya lebih dari delapan jam $(83,3 \%)$. Sapi yang diberikan pakan lengkap (rumput+konsentrat) cenderung lebih rendah yakni sebanyak 22,8\% sedangkan sapi yang diberikan pakan rumput saja sebanyak $77,2 \%$. Tanda-tanda ternak sapi yang mengalami berahi seluruhnya tampak jelas $(100,0 \%)$ dan tampak manajemen pemeliharaan ternak sapi $100 \%$ dikandangkan. Dari 114 ekor ternak sapi betina yang dilakukan IB, sebanyak 76,3\% mengalami kebuntingan dan $23,7 \%$ tidak mengalami kebuntingan.

Faktor-faktor yang memengaruhi keberhasilan IB pada sapi di Kabupaten Asahan disajikan dalam Tabel 3. Uji stepwise regression dengan variabel dependen yaitu status keberhasilan IB dan variabel independen meliputi umur sapi, jenis sapi yang di IB, skor kondisi tubuh sapi, waktu pelaksanaan IB, bulan dilakukannya IB, lama berahi pascapartus, jenis straw, dosis inseminasi, jarak pelaporan sampai IB, pakan sapi, tanda berahi dan dikandangkan (ya/tidak) diketahui bahwa variabel independen yang mempunyai korelasi paling kuat adalah umur sapi (sig. 0,006), jarak pelaporan sampai IB (sig. 0,001), serta pakan ternak sapi (sig. 0,004). Ketiga faktor yang mempunyai korelasi paling kuat didapat berdasarkan sig. <0,05 sehingga memiliki pengaruh yang nyata terhadap keberhasilan IB di Kabupaten Asahan, dengan persamaan regresi $\mathrm{Y}=-2,459+1,830 \mathrm{X} 1+$ $2,158 \mathrm{X} 2+2,635 \mathrm{X} 3$, Y adalah keberhasilan IB sedangkan $\mathrm{X} 1$ adalah umur sapi, X2 adalah jarak pelaporan sampai IB dan X3 adalah pakan ternak sapi.

Fertilitas betina dapat dilihat dari adanya kebuntingan, kondisi saluran reproduksi, pakan yang diberikan, perubahan kondisi tubuh dari kelahiran sampai perkawinan kembali, umur dan bangsa (Ihsan dan Wahjuningsih, 2011). Ternak sapi dara lebih tinggi fertilitasnya bila dibandingkan dengan ternak dewasa, fertilitas sapi dara akan meningkat sampai umur 4 tahun, kemudian akan stabil sampai umur 6 tahun, setelah itu akan menurun secara bertahap (Salisbury dan van Demark, 1985). Hal ini sesuai dengan data penelitian yang menunjukkan peternak pada lima kecamatan di Kabupaten Asahan cenderung melakukan IB pada ternak sapi dengan umur 4-6 tahun 84,2\%. Selanjutnya berdasarkan hal tersebut sangat besar kemungkinan bahwa keberhasilan inseminasi buatan pada sapi dara dan sapi yang pernah beranak yang berumur kurang dari 6 tahun akan lebih tinggi apabila dibandingkan dengan ternak dewasa yang berumur lebih dari 6 tahun (Salisbury dan Van Demark, 1985).

Tabel 3. Hasil analisis stepwise regression terhadap faktor-faktor yang berpengaruh pada keberhasilan inseminasi buatan (The results of stepwise regression analysis on the factors that influence the success of artificial insemination)

\begin{tabular}{lcc}
\hline Faktor pengaruh keberhasilan IB (AI success factors) & Sig. & B \\
\hline Umur sapi (Age of cattle) & 0,006 & 1,830 \\
Lama pelaporan sampai IB (Interval reporting time to AI) & 0,001 & 2,158 \\
Pakan sapi (Types offeed) & 0,004 & 2,635 \\
Konstanta (Constanta) & 0,006 & $-2,459$ \\
\hline
\end{tabular}

Keterangan: Sig. <0,05 = memiliki pengaruh yang nyata (had significant effect); $\mathrm{B}=$ nilai koefisien regresi (regression coefficient value) 
Umur memiliki peranan yang cukup penting misalnya umur pertama kali beranak sangat memengaruhi produktivitas ternak tersebut sebab ternak yang dikawinkan pada umur yang terlalu muda atau pertama kali pubertas akan menyebabkan bobot badan tidak dapat optimal dan keturunan yang dihasilkan juga akan mengalami hal yang sama, serta ketika partus ternak akan mengalami kesulitan (Zainudin et al., 2014). Dalam kondisi tertentu, perkawinan betina sengaja ditunda dengan maksud agar ternak tidak beranak terlalu kecil untuk menghindari terjadinya distokia (Lindsay et al., 1982). Sapi dara yang tidak dikawinkan sampai melebihi umur dan besar badan yang seharusnya telah dikawinkan pertama kali, akan menyebabkan penampilan reproduksi selama hidupnya rendah (Destinawati dan Isnaini, 2010).

Reksohardiprojo (1985), menyatakan bahwa masa birahi, lama birahi dan masa bunting ternak perlu diketahui peternak untuk mendapatkan hasil yang baik dari perkawinan ternak. Waktu optimum untuk melakukan inseminasi harus diperhitungkan dengan waktu kapasitasi, yaitu suatu proses fisiologik yang dialami oleh spermatozoa di dalam saluran kelamin betina untuk memperoleh kapasitasi atau kesanggupan membuahi ovum. Waktu inseminasi pada sapi dianjurkan tidak boleh kurang dari 4 jam sebelum ovulasi atau tidak boleh melebihi 6 jam sesudah estrus (Toelihere, 1997).

Data hasil penelitian menunjukan bahwa tingkat keberhasilan IB dengan jarak pelaporan sampai dilaksanakaannya IB umumnya lebih dari delapan jam 83,3\%. Hal ini sesuai dengan Syarif dan Soemoprastowo (1984), agar berlangsungnya konsepsi yang baik perlu diketahui waktu yang tepat untuk mengawinkan sapi, lama saat birahi adalah 6-36 jam dengan rata-rata 18 jam pada sapi betina dewasa dan 15 jam pada sapi betina dara. Djanah (1985), menyatakan bahwa 0- 6 jam setelah gejala birahi terlalu awal untuk diinseminasi yaitu 6-10 jam dan 20-30 Jam setelah birahi merupakan waktu yang baik untuk inseminasi buatan dan setelah 20-30 jam setelah birahi sudah terlambat untuk inseminasi.

Menurut Trimberger dan Davis (1943), inseminasi pada sapi antara 8-24, khususnya 7-18 jam, sebelum ovulasi akan memberikan angka konsepsi yang paling tinggi. Deteksi berahi harus dilakukan paling sedikit dua kali sehari, di pagi dan petang dengan teliti 20-60 menit (Toelihere, 1997). Untuk kepentingan IB, sapi-sapi yang nampak berahi pada pagi hari, sebaiknya diinseminasi sore itu juga dan sapi yang nampak berahi sore, hendaknya dikawinkan besok pagi hari (Adnan, 2018). Pelaksanaan IB sebaiknya tidak dilakukan pada siang hari, karena lendir servik mengental pada siang hari, sedangkan pada pagi, sore maupun malam, lendir serviks menjadi encer, hal tersebut juga berdampak pada keberhasilan IB saat siang yang lebih rendah dari pada saat pagi, sore atau malam hari (Susilawati, 2000 yang disitasi Wahyudi et al., 2013).

Sariubang (2006) menyatakan bahwa pakan diperlukan untuk hidup pokok, pertumbuhan, reproduksi dan produksi daging dan juga menjadi hal pendukung dalam pelaksanaan program IB. Hal ini sesuai dengan Hardjopranjoto (1995), yang berpendapat agar proses reproduksi berjalan dengan normal, diperlukan ransum pakan yang memenuhi kebutuhan pertumbuhan maupun reproduksi. Kemampuan sapi betina untuk bunting pada inseminasi pertama sangat dipengaruhi oleh nutrisi pakan yang diterima sebelum dan sesudah beranak. Pakan merupakan komponen utama untuk keberhasilan usaha peternakan (Kojo et al., 2015). Winugroho (1991), kelemahan sistem produksi peternakan terletak pada tidak tepatnya pengelolaan pemberian pakan. Ketersediaan pakan hijauan perlu diperhatikan baik secara kualitas maupun kuantitasnya untuk meningkatkan produktifitas ternak khususnya ruminansia.

Pemberian pakan hijauan di lokasi penelitian lebih tinggi persentasi tidak bunting yakni $92,6 \%$ dan yang berhasil bunting $72,4 \%$ dibandingkan dengan pemberian pakan lengkap (rumput + konsentrat) lebih tinggi persentase bunting yakni $27,6 \%$ dan yang tidak bunting 7,4\%. Dapat disimpulkan bahwa di lokasi penelitian yang berpengaruh nyata terhadap keberhasilan IB adalah pemberian pakan lengkap (rumput + konsentrat). Hal ini sesuai dengan pendapat Nuschati (2008) yang mengatakan bahawa sebaiknya hijauan dan konsentrat diatur sedemikian rupa agar seimbang. Pemberian pakan hijauan sebanyak $10 \%$ dari bobot tubuh, dan pakan tambahan berupa konsentrat sebanyak 12\% dari bobot tubuh. Pakan tambahan berupa konsentrat merupakan salah satu sumber gizi tinggi, mineral dan protein.

Arthur (2001) mengatakan bahwa salah satu nutrisi yang terkandung dalam pakan tambahan konsentrat adalah karbohidrat, bentuk paling sederhana bisa berupa aldehid (polihidrosialdehid atau aldosa) atau berupa keton (polihidroksiketon atau ketosa). Rendahnya kadar glukosa dalam serum sapi, selain dapat menghambat sintesis atau pelepasan gonadotrophin releasing hormone $(\mathrm{GnRH})$ juga dapat menghambat pelepasan follicle stimulating hormone (FSH) dan luteinizing hormone (LH), 
sehingga menghambat perkembangan folikel, ovum, estrogen dan progesteron, menyebabkan efek toksis terhadap folikel, oosit, embrio dan fetus karena tidak cukupnya hormon steroid ovarium.

\section{SIMPULAN}

Faktor-faktor yang memengaruhi keberhasilan inseminasi buatan pada sapi di Kabupaten Asahan adalah umur sapi, jarak waktu pelaporan hingga pelaksanan inseminasi buatan, dan jenis pakan

\section{DAFTAR PUSTAKA}

Adnan, D.T.J. 2018. Evaluasi Keberhasilan Inseminasi Buatan pada Sapi Berdasarkan Service Per Conception, Non-Return Rate dan Jenis Semen Beku yang Digunakan di Kecamatan Narmada Kabupaten Lombok Barat. Skripsi. Fakultas Peternakan, Universitas Mataram.

Ananta, A., H. Hafid, dan L.O.A. Sani. 2015. Faktor-faktor yang mempengaruhi produktifitas usaha ternak sapi bali pada peternakan transmigran dan non transmigran di Pulau Kabaena Kabupaten Bombana. J. Ilmu Ternak Tropika. 2(3): 52-67.

Annisa, N. N., Roslizawaty, Hamdan, C.D. Iskandar, Ismail, dan T.N. Siregar. 2018. Peran peternak terhadap keberhasilan inseminasi buatan pada sapi di Kabupaten Asahan. JIMVET. 2(1): 155-160.

Arthur, G.H. 2001. Veterinary Reproduction and Obstetrics. W. B. Saunders, England.

Astuti, T., Abungamar, Siswadi, dan Y. Subagiyo. 2000. Studi perbaikan keuntungan peternak kambing perah di Kecamatan Kaligesing Kabupaten Purworejo. J. Anim. Product. Edisi Khusus: 260-267.

Delfina, Y. 2001. Faktor penunjang kegagalan pelaksanaan IB di KPBS Pangalengan, Bandung (Periode Januari 1999 sampai Januari 2000). Skripsi. Fakultas Kedokteran Hewan, Institut Pertanian Bogor, Bogor.

Destinawati, N. dan N. Isnaini. (2010). Penampilan reproduksi sapi peranakan simental di Kabupaten Tulungagung Jawa Timur. J. Ternak Tropika. 11(2): 41-47.

Djanah, D. 1985. Mengenal Inseminasi Buatan. CV. Simplex, Jakarta.

Hardjopranjoto, S. 1995. Ilmu Kemajiran Pada Ternak. Airlangga University Press. Surabaya.
Hastuti, D. 2008. Tingkat keberhasilan inseminasi buatan sapi potong ditinjau dari angka konsepsi dan service per conception. Mediagro. 4(1): 12-20.

Hastuti, D. 2008a. Kajian sosial ekonomi pelaksanaan inseminasi buatan sapi potong di Kabupaten Kebumen. Mediagro. 4(2): $1-12$.

Hifiziah, A. dan Astuti. 2015. Analisis faktor keberhasilan inseminasi buatan ternak sapi potong di Kecamatan Tomnolo Pao Kabupaten Gowa. J. Teknosains. 9(1): 1326.

Hoesni, F. 2015. Pengaruh keberhasialn inseminasi buatan (IB) antara sapi bali dara dengan sapi bali yang pernah beranak di Kecamatan Pemayung Kabupaten Batanghari. J. Ilmiah Universitas Batanghari Jambi. 15(4): 20-27.

Ihsan, M.N. 2010. Indeks fertilitas sapi PO dan persilangannya dengan Limousin. $J$. Ternak Tropika. 11(2): 82-87.

Ihsan, M.N. dan S. Wahjuningsih. 2011. Penampilan reproduksi sapi potong di Kabupaten Bojonegoro. J. Ternak Tropika. 12(2): 76-80.

Kojo, R.M., Rustandi, Y.R.L. Tulung, dan S.S. Malalantang. 2015. Pengaruh penambahan dedak padi dan tepung jagung terhadap kualitas fisik silase rumput gajah. $J$. Zootek. 35(1):21-29.

Kusnadi, U.S., Prawirokusumo, dan Sabarani. 1983. Efisiensi Usaha Peternak Sapi Perah yang Tergabung Dalam Koperasi di Daerah Istimewa Yogyakarta. Prosiding Ruminansia Besar. Pusat Penelitian dan Pengembangan Peternakan. Departemen Pertanian, Bogor.

Kusumawati, E.D. dan H. Leondro. 2014. Inseminasi Buatan. Unikama, Malang.

Lindsay, D.R., B. Enwistle, dan A. Winantea. 1982. Reproduksi Ternak di Indonesia. Fakultas Peternakan Universitas Brawijaya. Malang.

Malotes, J. 2016. Strategi pengembangan usaha peternakan sapi potong di Kecamatan Tinangkung Utara Kabupaten Banggai Kepulauan. J. Agroland. 23(3): 198-207.

Mosher, A.T. 1987. Menggerakkan dan Membangun Pertanian. Yasaguna, Jakarta.

Nuryadi dan S. Wahjuningsih. 2011. Penampilan reproduksi sapi peranakan Ongole dan peranakan Limousin di Kabupaten Malang. J. Ternak Tropika. 12(1): 76-81.

Nuschati, U. 2008. Teknologi Formulasi Ransum untuk Penggemukan Sapi pada Wilayah 
Marjinal. https://adoc.tips/teknologiformulasi-ransum-untuk-penggemukansapi-pada-wilay.html

Prayitno, R.S. 2018. Analisis usaha ternak indukan sapi peranakan Simental di Kecamatan Patean Kabupaten Kendal. Agromedia 36(1): 97-105.

Reksohadiprodjo, S. 1985. Pengembangan Peternakan di Daerah Transmigrasi. BPFE, Yogyakarta.

Sabrani, M. 1989. Perilaku Petani Ternak Domba Dalam Alokasi Sumber Daya Studi Kasus Di Mijen dan Klepu Jawa Tengah. Disertasi. Program Doktor Pascasarjana Universitas Gadjah Mada. Yogyakarta.

Salisbury, G.W. dan N.L. Van Demark. 1985. Fisiologi Reproduksi dan Inseminasi Buatan pada Sapi. Gajah Mada University Press, Yogyakarta.

Sariubang, M. 2006. Pengkajian Teknologi Pembibitan Sapi Potong Berbasis Pedesaan Mendukung Swasembada Daging di Sulawesi Selatan. http://www.sulsel.litbang.pertanian.go.id

Selk, G. 2007. Artificial Insemination For Beef Cattle. Division of Agricultural Sciences and Natural Resources. Oklahoma State University. http://osuextra.okstate.edu.

Sibagariang, M., Z. Lubis, dan Hasnudi. 2010. Analisis pelaksanaan inseminasi buatan (IB) pada sapi dan strategi pengembangannya di Provinsi Sumatera Utara. Agrica. 1(1): 27-36.

Soekartawi. 1988. Prinsip Dasar Ekonomi Pertanian. Penerbit Rajawali. Jakarta.

Susilawati, T. 2011. Tingkat keberhasilan inseminasi buatan dengan kualitas dan deposisi semen yang berbeda pada sapi peranakan Ongole. J. Ternak Tropika. 12(2): 15-24.

Syarif, M.Z. dan R.M. Sumoprastowo. 1984. Ternak Perah. CV. Yasaguna, Jakarta.

Toelihere, M. R. 1997. Fisiologi Reproduksi Pada Ternak. Angkasa, Bandung.

Trimberger, G.W. dan G.K. Davis. 1943. The relationship between time of insemination and breeding efficiency in dairy cattle. Nebr. Agr. Expt. Sta. Res. Bul.:129.

Wahyudi, L., T. Susilawati, dan S. Wahyuningsih. 2013. Tampilan reproduksi sapi perah pada berbagai paritas di Desa Kemiri Kecamatan Jabung Kabupaten Malang. $J$. Ternak Tropika. 14(2): 13-22.

Winugroho, M. 1991. Pedoman Cara Pemanfaatan Jerami pada Pakan Ruminansia. Balai Penelitian Ternak, Bogor.

Zainudin, M., M.N. Ihsan, dan Suyadi. 2014. Efisiensi reproduksi sapi perah PFH pada berbagai umur di CV. Milkindo Berka Abadi Desa Tegalsari Kecamatan Kepanjen Kabupaten Malang. J. Ilmu-Ilmu Peternakan. 24(3): 32-37. 